\title{
Structural and Ecological Characteristics of Tree Communities in the Forest of Pobe in Southeast Benin
}

\author{
Armand Kingbo*, Adek Rolex Aurel Agbo, Jean Cossi Ganglo \\ Laboratory of Forest Sciences (LSF), Faculty of Agricultural Sciences (FSA), University of Abomey-Calavi (UAC), Abomey-Calavi, Benin
}

Email address:

armandkingbo@gmail.com (A. Kingbo), araagbo@gmail.com (A. R. A. Agbo), ganglocj@gmail.com (J. C. Ganglo)

*Corresponding author

\section{To cite this article:}

Armand Kingbo, Adek Rolex Aurel Agbo, Jean Cossi Ganglo. Structural and Ecological Characteristics of Tree Communities in the Forest of Pobe in Southeast Benin. Agriculture, Forestry and Fisheries. Vol. 10, No. 3, 2021, pp. 102-111. doi: 10.11648/j.aff.20211003.12

Received: April 19, 2021; Accepted: May 24, 2021; Published: May 31, 2021

\begin{abstract}
The main objective of this study is to determine the different tree communities in the forest of Pobè and characterize their structure and ecology to contribute to the sustainable management of this forest. The forest of Pobè is located between the parallels $6^{\circ}$ $57^{\prime} 20^{\prime \prime}$ and $6^{\circ} 58^{\prime} 04^{\prime \prime}$ north latitude and $2^{\circ} 39^{\prime} 46^{\prime \prime}$ and $2^{\circ} 40^{\prime} 45^{\prime \prime}$ east longitude. The sampling used for data collection is one central plot of 1 hectare $(100 \mathrm{~m}$ x $100 \mathrm{~m})$ at the center of a square of 4 ha $(200 \mathrm{~m}$ x $200 \mathrm{~m})$. Twenty-five plots were installed and the dendrometric measurements were taken on the trees $(\mathrm{dbh} \geq 10 \mathrm{~cm})$. The regeneration inventory was done in 125 quadrats of $100 \mathrm{~m}^{2}$ each at the rate of 5 quadrats per plot. The main results obtained showed that the forest of Pobè is diversified with 56 species of trees with an average density of 157 trees/ha and a basal area of $28.01 \mathrm{~m}^{2} /$ ha. The diameter structure shows that the trees of small diameters $(\leq 40 \mathrm{~cm})$ are the most represented, which presages a forest able of ensuring its own renewal. Two tree communities have been identified and characterized. The most representative is the community dominated by Triplochiton scleroxylon, Ceiba pentandra and Antiaris toxicaria and the community dominated by Triplochiton scleroxylon, Antiaris toxicaria and Terminalia superba. These two tree communities are well diversified and do not present a significant difference at the threshold of 5\% for the diversity indexes calculated. The biggest threat of loss of biodiversity and the forest of Pobè degradation is anthropization, marked by the presence of vegetation fires, fuelwood cutting for charcoal production and the traffic paths often source of forest fragmentation.
\end{abstract}

Keywords: Structure, Ecology, Tree Communities, Forest Degradation, Regeneration, Forest, Sustainable Management, Benin

\section{Introduction}

Forests constitute important natural resources through their ecosystem services, source of wood and non-wood forest products, and their environmental services such as biodiversity conservation, carbon sequestration, soil protection against erosion and the worship and cultural services $[1,2]$. In Benin, forest resources are quite limited. According to FAO [3], the forests of Benin cover an area of 3.135.000 ha. These resources are experiencing alarming degradation [4], under the combined effects of several factors including population growth, inappropriate cultivation practices, inefficient use of forests for timber and fuelwood production and the practice of late fires and transhumance $[3,5,6]$. Benin loses on average of 50,000 ha of forest each year at the rate of $1.04 \%$ [7]. To find a solution against the destruction of forest resources, the state of Benin has implemented since 1940 a policy of reforestation of the degraded areas [8]. According to Cerutti \& al. [9], sustainable forest management needs more than approved forest management plans. Serious studies therefore have to be undertaken to ensure a sustainable management of forest resources, which are limited to the understanding level of the forests state, their conditions of establishment and their organization in terms of structure, composition, regeneration and quantitative evaluation of the tangible and intangible benefits that can be derived from it [10]. However, some studies were already carried out, and had focused on some aspects of sustainable management of forest resources, in particular the studies using the phytosociological approach. A phytosociological approach is a reliable science of vegetation investigation because, it allows to identify forest stations which are the basis units for sustainable development and management of the forests [8, 11-16]. For this study in the forest of Pobè, focusing on the structural and ecological characterization of tree communities, sustainable management are essential for the 
safeguard and conservation of forest ecosystems and their biodiversity. Indeed, the works of Sokpon [17] and Yehouenou-Tessi [18], using the phytosociological approach, focused on the ecological research in the forest of Pobè by identifying and describing the plant communities and characterizing the structures of their trees for a sustainable management of the forest. This approch is also used in the studies of forest plantations $[19,20]$. The most important parameters to characterize a forest or forest species are the density and the distribution of stems by size categories and the spatial distribution [21]. Density is a valuable indicator of the quantity of resource that will be available and also of the silvicultural state of tree populations. The distribution is essential to provide information on the ecology of the species, the possible silvicultural constraints and the state of the resources. In addition, the spatial distribution of a species provides ideas on the space occupation by the species and can provide information on the dispersal mechanisms of the species as well as its favorite stations [22, 23]. To all this is added the problem of regeneration, which disadvantage the reconstitution of degraded forest areas. This reconstitution is subject to certain constraints such as the proximity of the seed sources, the characteristics of the species, the intensity of the disturbances, and the intrinsic factors of the site [1]. Despite these studies realized, an update of the current communities and other informations are still insufficient to facilitate sustainability decision-making by the managers of these forests. In the context of the present study, the main research questions that guided our investigations are as follows: what are the tree communities in the forest of Pobè and what characterizes their structure? What are the main characteristic species of these forest tree communities and what are their silvicultural problems? The answers to these questions guided us in giving the adequate recommendations for the sustainable management of the forest of Pobè. Thus, this study aims in overall to contribute to the sustainable management of forest resources in Benin. Specifically, it aims firstly to describe the tree communities of the forest of Pobè; secondly, to characterize the structure of these tree communities and their characteristic species and thirdly, to highlight the possible silvicultural problems of these characteristic species and give some recommendations to the sustainable management of the forest of Pobè.

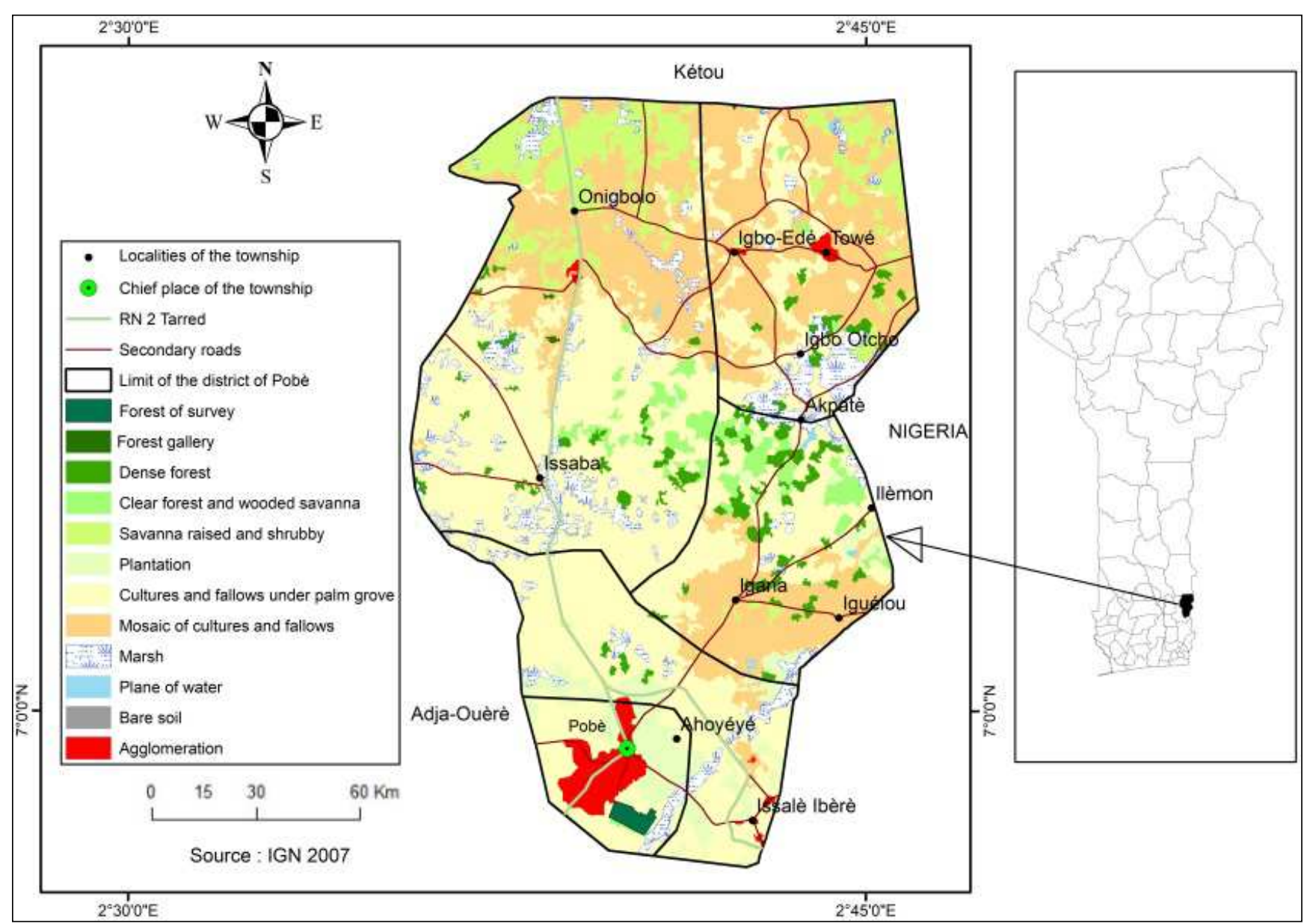

Figure 1. Geographical location of the studied forest in Benin and in the municipality of Pobè.

\section{Study Area}

This study took place in the classified forest of Pobè located between the parallels $6^{\circ} 57^{\prime} 20^{\prime}$ "and $6^{\circ} 58^{\prime} 04^{\prime \prime}$ North latitude and $2^{\circ} 39^{\prime} 46^{\prime \prime}$ and $2^{\circ} 40^{\prime} 45^{\prime \prime}$ East longitude (Figure 1). This forest covers an area of 115 ha and is located in the Southeast of Benin, in the department of Plateau and more precisely at 
the south end of the area of the Center for Agricultural Research on Perennial Plants (CRAPP). This classified forest of Pobè is submitted to a tropical humid or subequatorial climate characterized by two dry seasons alternating with two rainy seasons. The monthly variations in rainfall give an annual average rainfall of $1134 \mathrm{~mm}$ during the period from 1980 to 2016 . The monthly average temperatures turn around $25{ }^{\circ} \mathrm{C}$ with a difference of $2{ }^{\circ} \mathrm{C}$ around the average between the hottest month (February) and the coldest one (August). The maxima vary between $29^{\circ} \mathrm{C}$ and $35^{\circ} \mathrm{C}$ while the minima vary between $22{ }^{\circ} \mathrm{C}$ and $24{ }^{\circ} \mathrm{C}$. Humidity varies during the year between $68 \%$ and $85 \%$ with a large value ( 82 to $85 \%$ ) during the months of June to October. The geological formation that supports the soils in the study area is the terminal continental. The ferralitic soil is predominant in this forest and characterized by a humus stratum, which is generally followed by a silty-sandy horizon which becomes clayey at depth. The pedogenesis at the top of the slope presents red soils, which are sometimes not very leached and gravelly sandstone soils. At the bottom of the slope, we have colluvial soils, which are contributions from old erosion.

\section{Methods}

\subsection{Forest Inventory Method}

The data collection equipment is comprised of some materiel such as GPS (Global Positioning System), $\pi$ ribbons, penta decameter, Suunto clinometer, Suunto compass, digital camera. The inventory was carried out in 1 ha plot $(100 \mathrm{~m} \mathrm{x} 100 \mathrm{~m})$ systematically installed in the center of each square meshes of 4 ha $(200 \mathrm{~m} \times 200 \mathrm{~m})$. To avoid the border effect, each plot of 1 ha were installed at a minimum distance of $50 \mathrm{~m}$ from the border of the each 4 ha square mesh. In each plot, the dendrometric measurements such as diameters and height were taken on the trees $(\mathrm{dbh} \geq 10 \mathrm{~cm})$. A count of the potential for regeneration in the classified forest of Pobè was made. This potential were defined by the relative density of regeneration per hectare by the value species. This is the average number of regeneration tree species reduced per hectare. The regeneration densities of all species combined were calculated per quadrat of $100 \mathrm{~m}^{2}(10 \mathrm{~m} \times 10 \mathrm{~m})$ and then extrapolated to the hectare.

\subsection{Data Analysis}

\subsubsection{Individualization of Tree Communities}

In order to determine the tree communities in the forest, we analyzed the data matrix of the phytosociological inventories carried out using the $\mathrm{R}_{\mathrm{i} 3863.5 .1}$ software. The contingency table of the matrix was submitted to a factorial analysis of the correspondences followed by the ascending hierarchical classification which provided a dendrogram discriminating tree communities. Factorial Correspondence Analysis (CFA) is a method that allows studying the association between two qualitative variables according to Chessel [24].

\subsubsection{Floristic Parameters}

The following floristic parameters were calculated for each plot before the average were found by tree community or for the whole forest:

the specific richness $(\mathrm{S})$.

the Shannon Index $[25,26]$ :

$\mathrm{H}=-\sum_{i=1}^{s} \frac{n i}{n} \log _{2} \frac{n i}{n}$ with ni $=$ number of individuals of the species $\mathrm{i} ; \mathrm{n}=$ total number of trees inventoried in the plot.

Equitability of Pielou: $\mathrm{Eq}=\frac{H}{H \max }$ avec

Hmax $=\log _{2} \mathrm{~S}$ with Hmax is the Shannon theoretical maximum diversity index related to the stand; $\mathrm{S}$ is the specific richness.

\subsubsection{Structural and Ecological Characteristics of Forest Tree Communities}

The density of each plot, community and for the forest was calculated with the formula $N=\frac{n}{\boldsymbol{s}}$ where $n$ is the total number of trees per 1 ha plot; $\mathrm{S}=$ area of the plot which is equivalent to 1 ha.

The quadratic mean diameter $(D g)$ per plot, community and for the forest was calculated. $D g_{p}=\sqrt{\frac{1}{n} \sum_{i=1}^{n} d i^{2}}$; with $\mathrm{n}$ the number of trees with $\mathrm{dbh} \geq 10 \mathrm{~cm}$ inside the plot and di is the diameter in $\mathrm{cm}$ of tree $\mathrm{i}$.

The basal area $\left(\mathrm{G}\right.$, in $\left.\mathrm{m}^{2} / \mathrm{ha}\right)$ at the reference level $(1.3 \mathrm{~m}$ from the ground) was calculated for each plot, community and for the forest.

$\mathrm{G}=\frac{\pi \sum_{i=1}^{n} d i^{2}}{4 s} 10^{-4} ; d i$ is the diameter (in $\mathrm{m}$ ) of each tree $i$ of the plot.

The distributions of the diameter classes were also carried out with an amplitude of $5 \mathrm{~cm}$ in the diameter classes in order to analyze the diameter structures of different species within tree communities and for the forest.

\subsubsection{Characterization of Regeneration}

Two regeneration classes were considered based on the work of Feeley [27] and Ali [28]: the class of juveniles: $10 \mathrm{~mm} \leq \mathrm{dbh}$ $<50 \mathrm{~mm}$ and the class of poles: $50 \mathrm{~mm} \leq \mathrm{dbh}<100 \mathrm{~mm}$.

The regeneration density of each quadra and plots is calculated as follows:

$$
N_{r}=\frac{1}{3} \sum_{i=1}^{3} d_{r i}
$$

With

$$
d_{r i}=\frac{n_{i}}{s_{q}}
$$

$\mathrm{Nr}$ is the average regeneration density per plot expressed in subjects per hectare, $d r i$ is the regeneration density in each of the five quadrats of $100 \mathrm{~m}^{2}$ in a plot (i) of the 1 ha plot considered, $n_{i}$ is the number of regenerations counted over the $i$ quadrat and $s_{q}$ the area of the quadrat in ha $\left(s_{q}=0,01 \mathrm{ha}\right)$.

\subsubsection{Comparison of Means}

The tree communities were compared for the structural and floristic parameters calculated using an analysis of variance test (ANOVA) and the nonparametric Kruskal-Wallis test with the $\mathrm{R}_{\mathrm{i} 386-3.5 .1}$ software. 


\section{Results}

\subsection{Floristic Diversity of the Forest}

Table 1 shows the floristic diversity of the whole forest. Pobè forest has 56 tree species, gender and families combined. The Shannon diversity index values ( 4.53 bits) obtained prove that the forest of Pobè is very diverse and that the species are co-dominant.

Table 1. Floristic diversity of trees $(\mathrm{dbh} \geq 10 \mathrm{~cm})$ of the Pobè forest.

\begin{tabular}{ll}
\hline Diversity indices & Value \\
\hline Specific richness (S) & 56 \\
Shannon Diversity Index (H) & 4,53 \\
Equitability of Pielou (Eq) & 0,78 \\
\hline
\end{tabular}

\subsection{Structural Characteristics of the Forest of Pobè}

The dendrometric parameters calculated over the whole forest (all individuals combined) are summarized in Table 2 below.

Table 2. Dendrometric parameters of the entire Pobè forest.

\begin{tabular}{llll}
\hline Parameters & Mean & $\boldsymbol{\delta}$ & CV (\%) \\
\hline $\mathrm{N}$ trees / ha & 157,92 & 10,13 & 8,56 \\
$\mathrm{Dg}$ in cm & 48 & 0,02 & 3,37 \\
$\mathrm{G} \mathrm{m}$ /ha & 28,01 & 1,88 & 11,23 \\
\hline
\end{tabular}

$\mathrm{NB}$ : $\mathrm{N}$ tree density in trees / ha, Dg quadratic mean diameter in $\mathrm{cm}, \mathrm{G}$ basal area in $\mathrm{m}^{2} /$ ha

It emerges from the analysis of Table 2 that the density of trees in the forest of Pobè is 157 trees per hectare, and that this value is relatively low for this type of dense formation. The average diameter of the trees $(48 \mathrm{~cm})$ as well as the basal area $\left(28.01 \mathrm{~m}^{2} / \mathrm{ha}\right)$ show relatively average values.

\subsection{Diameter Structure of the Whole Forest of Pobè}

Figure 2 shows the distribution in diameter classes of the trees inventoried in the Pobè forest.

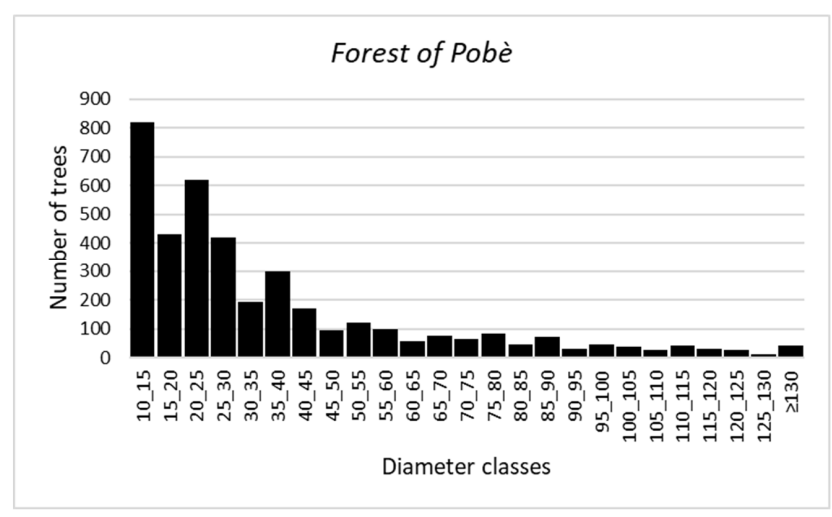

Figure 2. Diameter structure of the entire Pobè forest.

Analysis of the diameter structure of the whole forest of Pobè shows that the tree diameters distribution presents an "inverted J" diameter distribution, which characterizes uneven, undisturbed stands. In this same figure, we note that individuals whose diameter varies between $10 \mathrm{~cm}$ and $15 \mathrm{~cm}$ are the most represented, with a density of 33 trees / ha.

\subsection{Identification of Tree Communities of Trees in the Forest}

The results of the factorial analysis of correspondences and the hierarchical classification carried out on the data matrix (Figure 3 ) of the forest of Pobè show four communities of the plots according to their similarities summarized in Table 3.

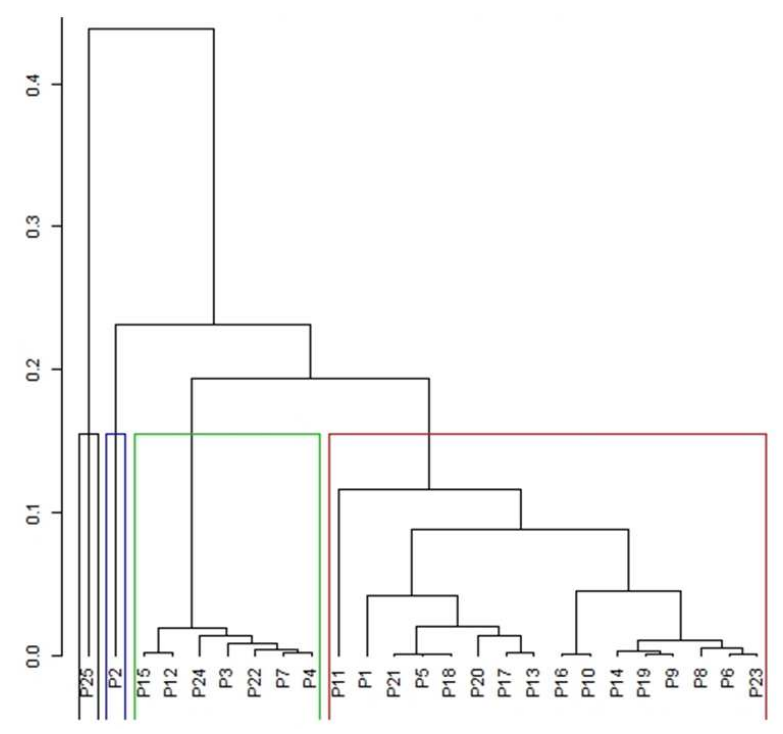

Figure 3. Ascending hierarchical classification of tree communities.

The figure 3 above shows the hierarchical classification carried out after the factorial analysis of Correspondences on the plots; there are communities according to their similarity. Therefore, we can distinguish four different communities of the plots, which have made it possible to define four tree communities of trees within the forest of Pobè. However, community 1 and 4 are less representative in the forest. In the following analyzes, we just take into account the communities 2 and 3 and these communities are distributed linearly as show by the Figure 4 .

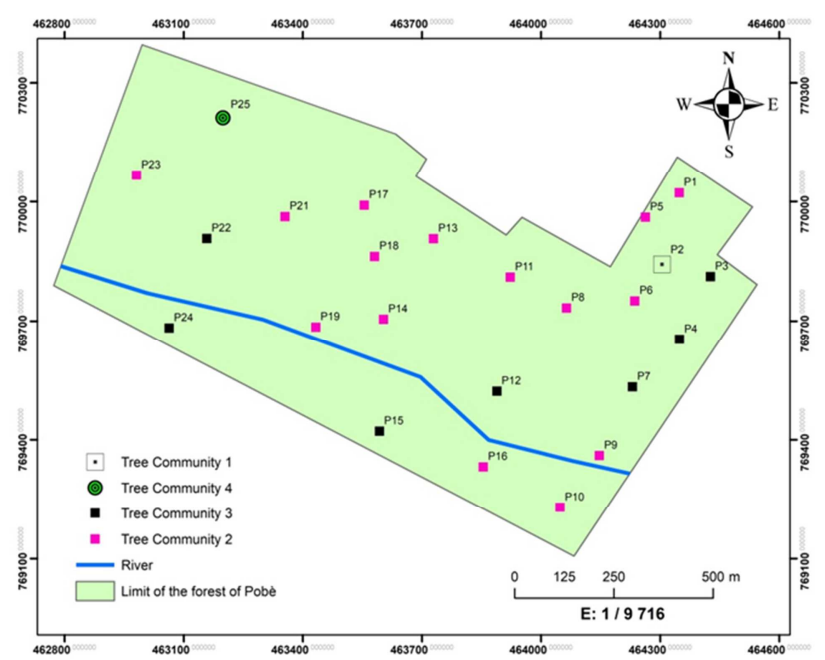

Figure 4. Distribution of tree communities identified in the Pobè forest. 
Table 3. Identified tree communities.

\begin{tabular}{|c|c|c|}
\hline $\begin{array}{l}\text { Identified } \\
\text { communities }\end{array}$ & $\begin{array}{l}\text { Number of } \\
\text { plots }\end{array}$ & $\begin{array}{l}\text { Identification of Plots }\left(P_{i}\right) \text { in each } \\
\text { community }\end{array}$ \\
\hline Community 1 & 01 & $\mathrm{P} 25$ \\
\hline Community 2 & 16 & $\begin{array}{l}\text { P1-P21-P18-P11-P20-P16-P13-P17-P1 } \\
\text { 0-P14-P19-P9-P8-P23-P6-P5 }\end{array}$ \\
\hline Community 3 & 07 & P15-P12-P24-P3-P22-P7-P4 \\
\hline Community 4 & 01 & $\mathrm{P} 2$ \\
\hline
\end{tabular}

\subsection{Species Characteristic of the Most Representative Tree Communities}

The values of the importance value index of the species calculated allowed distributing in order the characteristic species of each tree community represented in the forest of Pobè as presented in Tables 4 and 5 below respectively for the tree communities 2 and 3 .

Table 4. IVIE of the species present in the tree community 2.

\begin{tabular}{|c|c|c|c|c|c|c|}
\hline Species & Nber/s pecies & Gi & RF & RC & RD & IVIE \\
\hline Triplochiton scleroxylon & 392 & 66,3 & 0,16 & 0,17 & 1,00 & 1,33 \\
\hline Ceiba pentandra & 170 & 99,5 & 0,07 & 0,26 & 1,00 & 1,36 \\
\hline Antiaris toxicaria & 215 & 86,2 & 0,09 & 0,22 & 1,00 & 1,31 \\
\hline Dialium guineense & 336 & 12,5 & 0,14 & 0,03 & 1,00 & 1,17 \\
\hline Phyllantus & 185 & 3,9 & 0,08 & 0,01 & 0,93 & 1,02 \\
\hline Celtis adolfifrederici & 140 & 15,1 & 0,06 & 0,04 & 0,86 & 0,95 \\
\hline Millettia thonningui & 69 & 3,7 & 0,03 & 0,01 & 0,86 & 0,90 \\
\hline
\end{tabular}

Analysis of Table 4 shows that Triplochiton scleroxylon, Ceiba pentandra and Antiaris toxicaria are the characteristic species of the vegetation physiognomy of the community 2 in the forest of Pobè.

Table 5. IVIE of the species present in tree community 3.

\begin{tabular}{llllll}
\hline Species & Individuals of the species & Gi & RF & RC & IVIE \\
\hline Triplochiton scleroxylon & 203 & 56,983 & 0,195 & 0,24 & 1,0 \\
Antiaris toxicaria & 64 & 35,909 & 0,062 & 0,15 & 1,44 \\
Terminalia superba & 69 & 28,480 & 0,066 & 0,12 & 1,0 \\
Piptadeniastrum africanum & 60 & 24,946 & 0,058 & 0,11 & 1,21 \\
Ceiba pentandra & 49 & 19,681 & 0,047 & 0,08 & 1,0 \\
Cleistopholis patens & 76 & 6,384 & 0,073 & 0,03 & 1,0 \\
Celtis adolfifrederici & 41 & 7,372 & 0,039 & 0,03 & 1,0 \\
Dialium guineense & 46 & 3,527 & 0,044 & 0,01 & 1,13 \\
\hline
\end{tabular}

Table 5 shows the most characteristic species of community 3. It emerges from the analysis of this table that Triplochiton scleroxylon, Antiaris toxicaria and Terminalia superba are the most representative species in community 3 identified in the dense semi-deciduous forest of Pobè.

\subsection{Structural Characteristics of Tree Communities}

\subsubsection{Dendrometric Parameters of Tree Communities}

The dendrometric parameters of the tree communities in the forest of Pobè are presented in Table 6. Two communities (2 and 3) were characterized. The density of trees at the level of tree communities varies from 148 to 173 individuals per hectare. The values of the quadratic mean diameter and the basal area vary respectively from $27.81 \mathrm{~m}^{2} /$ ha to $33.66 \mathrm{~m}^{2} /$ ha. The mean values of the density and the basal area of communities 2 and 3 do not show a significant difference at the level of 5\% threshold. From these parameters, the forest communities are then identical with almost the same number of trees from the same basal area. On the other hand, for the quadratic mean diameter, the calculated mean shows a significant difference at the $5 \%$ threshold and the highest value is noted for the community 2 .

Table 6. Dendrometric parameters of tree communities.

\begin{tabular}{|c|c|c|c|c|c|c|c|c|c|}
\hline Communities & $\mathbf{N}$ & $\delta \mathbf{N}$ & CV N\% & Dg & $\delta \mathrm{Dg}$ & CV Dg\% & G & $\delta G$ & CV G\% \\
\hline Community 2 & 173,6 & 10,83 & 7,94 & 0,45 & 0,015 & 3,86 & 27,81 & 1,9 & 10,96 \\
\hline Community 3 & 148,4 & 7,85 & 5,95 & 0,53 & 0,016 & 2,91 & 33,47 & 1,7 & 4,39 \\
\hline Probability of Normality test & 0,49 & & & 0,67 & & & 0,75 & & \\
\hline Probability of comparison test & $0,40^{\mathrm{k}}$ & & & $0,03 *$ & & & 0,21 & & \\
\hline
\end{tabular}

NB: $N$ = density, $G=$ Basal area, Dg = Quadratic diameter, $\delta$ = standard deviation, CV = coefficient of variation, $(\mathrm{k})$ non-parametric Kruskal-Wallis test, $(*)$ significant difference between the means of the variable.

\subsubsection{Diameter Structure of Tree Communities}

Figure 5 shows the diameter structure of trees from each tree community.

By analyzing these structures of trees in representative communities (2 and 3), we notice that the trees present an 
"inverted J" distribution characteristic of multispecies or uneven-aged stands. In the community 2 , trees with diameters between 10 and $30 \mathrm{~cm}$ are by far the most dominant. In addition, trees with a diameter between 10 and $40 \mathrm{~cm}$ are by far the most dominant in the community 3 identified in the forest of Pobè.
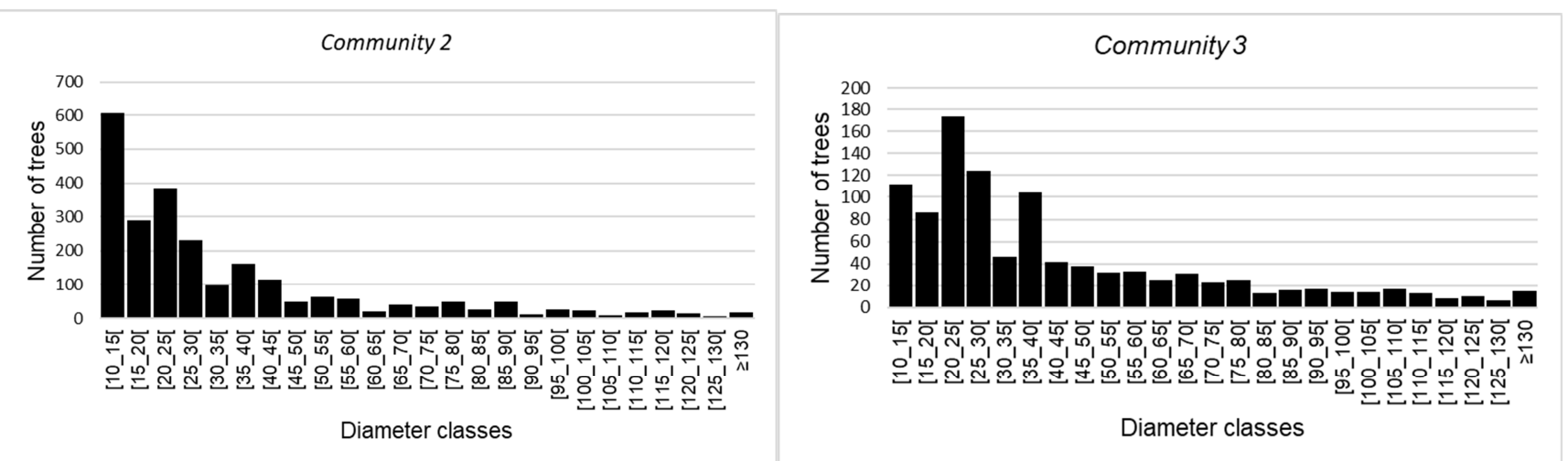

Figure 5. Diameter structure of tree individuals in tree communities.

\subsubsection{Diameter Structure of Caracteristic Species of Tree Communities}

Figure 6 shows the structure of the trees most represented in tree communities. Those trees are Triplochiton scleroxylon, Antiaris toxicaria, Ceiba pentandra and Terminalia superba.

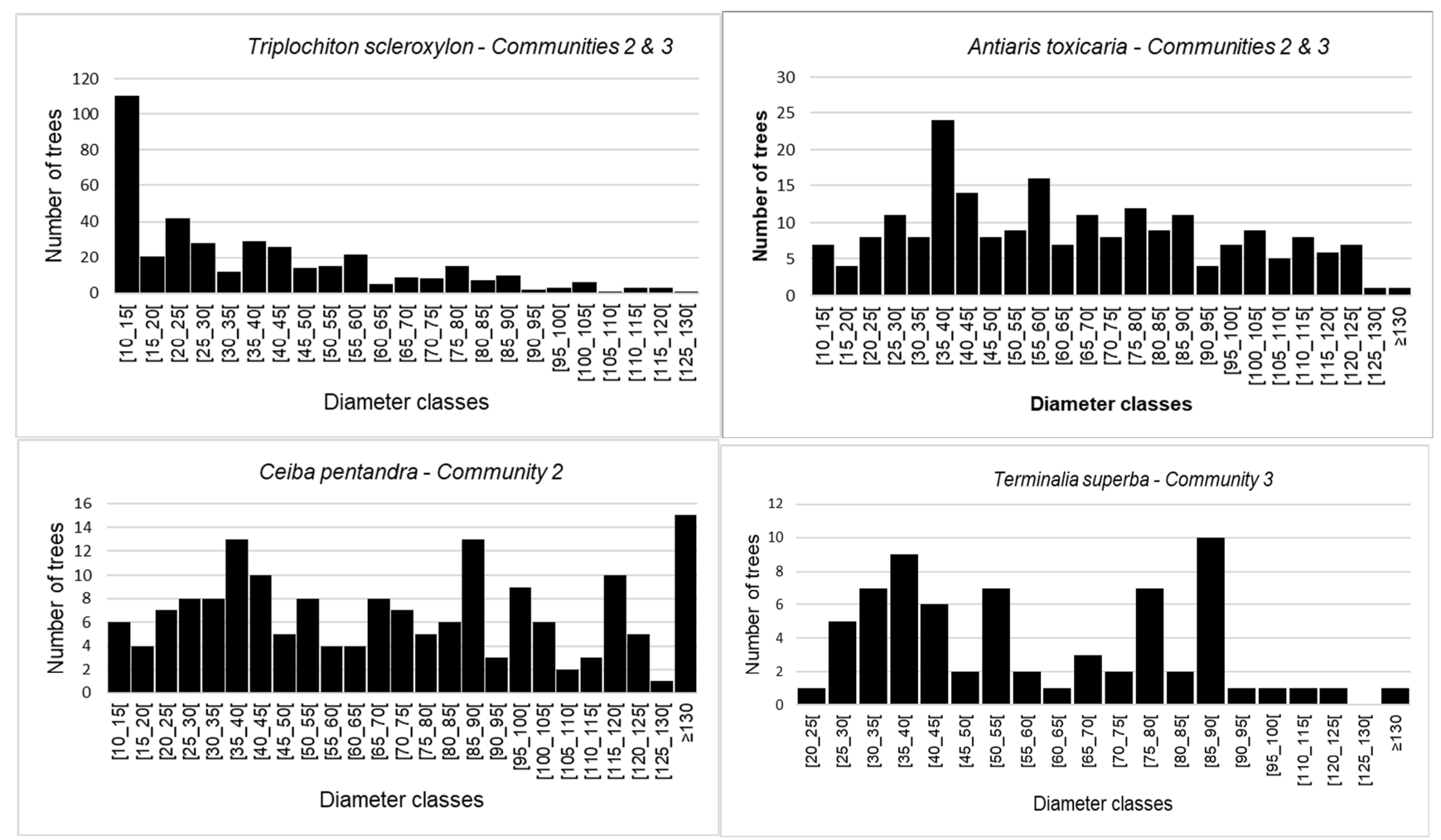

Figure 6. Diameter structure of valuable species of tree communities in the Pobè forest.

Figure 6 shows the diameter classes distribution of 4 dominant tree species in the two communities of trees representative in the forest of Pobè. Analysis of the figure shows that the species Triplochiton scleroxylon reveals an inverted J-shaped, structure characteristic of a young promising stand. The population diameter structure of the species Antiaris toxicaria, Ceiba pentandra and Terminalia superba shows an asymmetric left distribution, characteristic of stands with a predominance of trees with the diameter classes between $25 \mathrm{~cm}$ to $125 \mathrm{~cm}$.

\subsubsection{Floristic Diversity of Tree Communities}

Table 7 shows the values of the various parameters of floristic diversity for each of the tree communities of the classified forest of Pobè. The diversity of communities 2 and 3 is very high (4.18 bits, 4.21 bits). These values are characteristic of isotropic stations where species tend towards equiprobability. According to the values of the Pielou equitability Index, there is an absence of dominance in the 
community ( $\mathrm{Eq}$ is between $0.8 \& 0.98$ ). The specific richness varies between 42 and 46 species. The probabilities related to the comparison test of the two communities from the Shannon index, the Pielou Equitability and the specific richness are all superior to 0.05 , indicating an absence of significant difference between these two communities for the floristic parameters.

Table 7. Summary of diversity indices by tree communities in Pobè.

\begin{tabular}{lllll}
\hline Floristic parameters & Average Community 2 & Average Community 3 & Shapiro-Wilk Normality Test & Comparison test probabilities \\
\hline $\mathrm{H}$ & 4,18 & 4,21 & 0,000000097 & $0,3162^{\mathrm{k}}$ \\
$\mathrm{Eq}$ & 0,98 & 0,83 & 0,00000002986 & $0,4227^{\mathrm{k}}$ \\
$\mathrm{S}$ & 46 & 42 & 0,05383 & 0,551 \\
\hline
\end{tabular}

NB: (k) non-parametric Kruskal-Wallis test.

\subsubsection{Natural Regeneration of Tree Communities in the Pobè Forest}

Table 8 summarizes the comparison of the regeneration densities of the tree communities. At the level of juveniles and the class of young perch, the highest number is obtained at the level of community 3 : respectively (203 juveniles / ha) and (99 young perches / ha), while regeneration at the level of community 2 remains weak. The regenerations whose diameter is between 10 and $50 \mathrm{~mm}$ (juveniles), there is a very significant difference between the two communities with a higher average at the level of community 3 . On the other hand for the class of young perches the difference is not significant with the number of individuals reduced by more than half.

Table 8. Densities of regeneration of tree communities.

\begin{tabular}{llll}
\hline Parameters & Juveniles $(\mathbf{d}=[\mathbf{1 0}-\mathbf{5 0} \mathbf{~ m m}])$ & Poles $(\mathbf{d}>\mathbf{5 0} \mathbf{~ m m})$ & General \\
\hline & Average & Average & Average \\
Community 2 & 97,71 & 48 & 72,85 \\
Community 3 & 202,71 & 98,14 & 150,42 \\
Shapiro-Wilk Normality Test & 0,03206 & 0,3739 & 0,504 \\
Comparison test probabilities & $0,03206 \mathrm{k}$ & 0,504 \\
\hline
\end{tabular}

NB: Class 2 or juveniles: $10 \mathrm{~mm} \leq \mathrm{dbh} \leq 50 \mathrm{~mm}$; Class 3 or young perch: $50 \mathrm{~mm} \leq \mathrm{dbh} \leq 100 \mathrm{~mm}$. Avg: Average; (k) Kruskal-Wallis nonparametric test.

\section{Discussion}

\subsection{Floristic Diversity of the Forest, Threats and Conservation Measures}

The forest of Pobè is a relatively diverse community with 56 tree species $(\mathrm{dbh} \geq 10 \mathrm{~cm})$ identified in the framework of this study and which varies between 15 and 46 tree species at the level of the plots. These tree communities identified are also relatively diversified because of their Shannon index variation between 2.79 and 4.21 bits. Indeed, this study in the forest of Pobè follows on from the research works carried out in this forest, including the study of Sokpon [17]. The letter's work had made it possible to identify different phytocenoses of trees qualified as "forests", which correspond to the tree communities of the present study. Thus, [17] had obtained for phytocenoses, that the Shannon index varied between 3.17 and 5.3 bits and that this index increased from pioneer communities of windthrow to advanced stands. The specific richness in 1995 for trees varied between 47 and 51 species with a Piélou equitability index around 0.81 . Our study confirms these results in overall. But, some phytocenoses identified in 1995 were more diversified with the Shannon index values superior than 4.5 bits in the stand of trees; for example 4.71 for the tree community of Dialium guineense and Triplochiton scleroxylon and 4.95 bits for the tree community characterized by Strombosia glaucescens and Triplochiton scleroxylon. These values obtained in the present study are lower because for the community 3 characterized by Triplochiton scleroxylon, Antiaris toxicaria and Terminalia superba, the most diverse of the forest of Pobè, the average value obtained is 4.21 bits. The study of the forest of the community of the lower Valley of Ouémé (South-East Benin) conducted by Ali [28], revealed a specific richness of 78 species which shows that under the same climate and with the same variations in soil types, this forest is more diversified than the forest of Pobè. The forest of Pobè is relatively diversified because of the Shannon diversity index value which turn around 4.53 bits. However, of the four communities obtained, the most diverse are: community 2 dominated by Triplochiton scleroxylon, Ceiba pentandra and Antiaris toxicaria and community 3 dominated by Triplochiton scleroxylon, Antiaris toxicaria and Terminalia superba. The main activities that contribute to the degradation of the natural forest of Pobè and which could worsen it subsequently are agriculture, grazing, timber harvesting, fuelwood harvesting and charcoal process. Although under supervision, this forest is still threatened by the uncontrolled exploitation of its resources, which could in the long-term change some densely populated areas to become open forests. A more rational management of the trees harvesting from the forest could contribute to the conservation of its diversity. Areas where diversity is low, could be the subject of enrichment (Figures $7 \& 8$ ). The two figures show the gap in trees and an area dominated by herbaceous which covered the place after the windfall. 


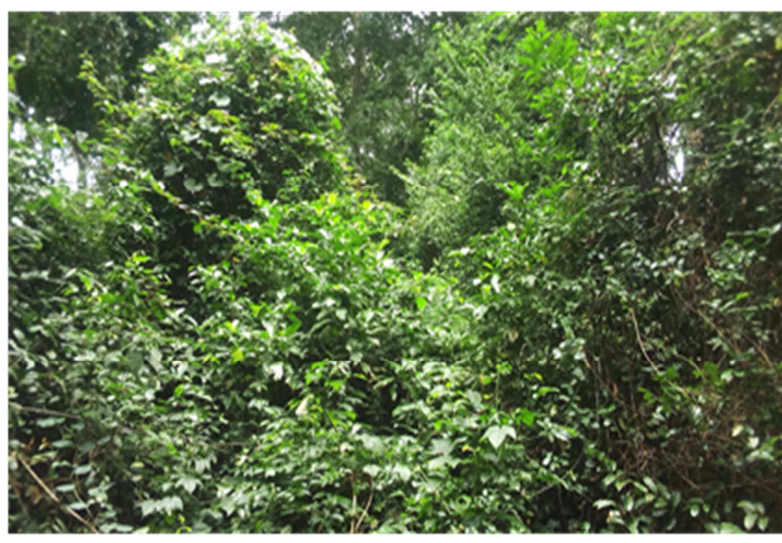

Figure 7. Gap created by the loading of firewood in the Pobè forest.

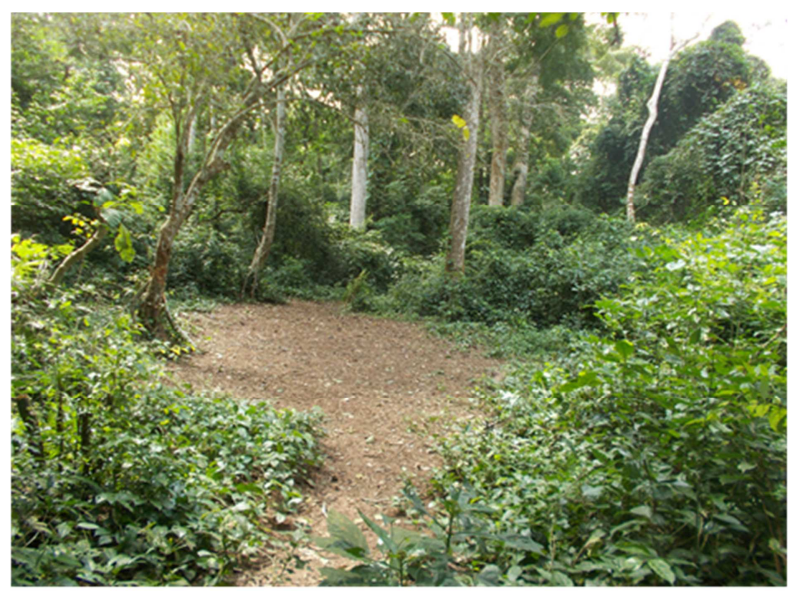

Figure 8. Gap with low floristic diversity in the Pobè forest.

\subsection{Structural Characteristics, Development and Sustainable Management of the Forest}

The management of forest stands requires the knowledge of the tree diameter structures. These structures are indicative of events linked to the life of the stands [29]. The study of tree communities in the forest of Pobè presents 4 tree communities, 2 of which are more represented. The density of trees in the communities varies from 51 to 198 stems / ha. These densities are lower than that obtained by Ahouandjinou [30] in the forest of Ouoghi in the municipality of Savè in Benin-center, which vary between 95 and 275 stems / ha despite the climate which is less favorable than in the south-east. This low tree density obtained reflects the canopy closure, which could prevent the evolution of the undergrowth of the forest because of the lack of the light. The diameter structure of the tree community 2 with Triplochiton scleroxylon, Ceiba pentandra and Antiaris toxicaria of the forest of Pobè shows an inverted $\mathrm{J}$ shape; which indicate that the highest densities are found in the small diameter classes. For Feeley [27], the high density of the small diameter classes ensure the future of the forest, which implies that the forest of Pobè have a good future. This situation shows that the renewal of old trees will be ensured if all the other environmental conditions were favorable and the influence of human is weak at the same time. The figure 9 shows the destructive effects of humans on forest trees in search of wood in the forest of Pobè.

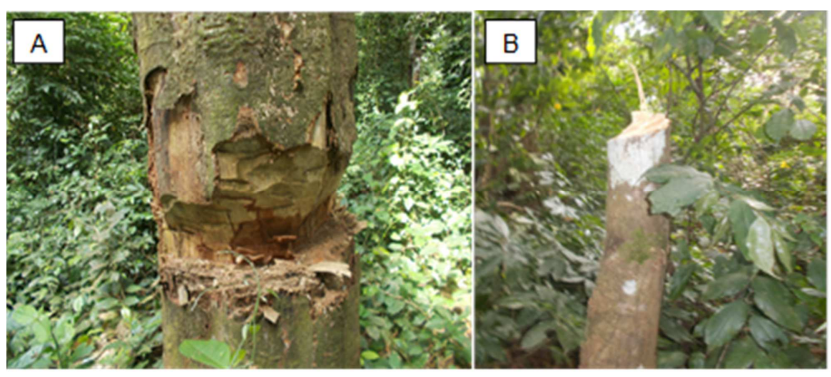

Figure 9. (A) Harvesting fuelwood; (B) cut poles for hoe and ax handles.

The management of this forest must take into account the biotope factors such as edaphic, environmental and climatic conditions, the regeneration process and the competition for resources. According to Herrero-Jáuregui [21] and Tchibozo [31], these environmental factors are decisive in the diameter class distribution of trees. The size of the big diameter classes is very low for the old trees. This is due to certain disasters like strong winds, which cause the fall of some old trees. Thus, the fraudulent forest resource exploitation observed in the forest of Pobè is a phenomenon that does not follow any management standard. However, we must not rely on the regeneration potential of the forest because the number of the young diameter classes does not guarantee satisfactory recruitment in the forest.

\section{Conclusion}

This study was carried out in the classified forest of Pobè located precisely at the southern end of the area of the Center for Agricultural Research on Perennial Plants (CRAPP). It has made it possible to characterize its structure and ecology to lead for proposal actions for its sustainable management. The average tree density in this forest is 157 trees per hectare; this value is relatively low compared to the results of previous work carried out in the same forest. The mean diameter of the trees as well as the basal area show relatively mean values and the trees of the forest follow an "inverted J" shaped distribution characterized by a dominance of individuals of the small diameter classes. This justifies that the forest is uneven with a good capacity of regeneration. The tree communities in the forest are much diversified with an average equitability value of Piélou index indicating that the species are co-dominant in the communities. The inventory made in the forest of Pobè made it possible to highlight two tree communities representatives according to their similarities. The dendrometric parameters, the diameter structure and the floristic diversity of the tree communities show that there is indeed a phenomenon of dominance between communities and that the factors of the environment constitute the discriminating element of the tree communities repartition. Although natural regeneration has a strong potential for forest recovery, it remains insufficient to ensure the sustainable management of the forest of Pobè. It is therefore important to implement an assisted natural regeneration ensuring the sustainability of forest ecosystem services. However, any management aiming the production of wood must be studied 
and should first find a solution to the illegal exploitation of wood by the local populations. Silvicultural operations aiming to increase the density of mature trees by opening the canopy should be implemented. These management objectives must aim to safeguard biodiversity by protecting and restoring natural vegetation with a strong involvement of local populations for participatory management. The sensitization is also a very important tool on which projects and programs can be inserted in order to influence local populations through the capacity building sections for customary leaders, religious, traditional therapists and loggers, on the subject of the sustainable management and conservation of the forest of Pobè. It is important to reduce exploitation in this forest while proposing new strategies for the diversification of economic activities capable of being implemented in this forest region of Benin. Some activities as beekeeping can be implemented in the forest also.

\section{Conflict of Interests}

The authors declare that there is no competing interest.

\section{Acknowledgements}

This research was financially supported by the International Foundation for Science (IFS) with Research Grant Agreement $\mathrm{N}^{\circ} \mathrm{D} / 6244-1$ awarded to the first author.

\section{References}

[1] Guariguata, M. R., Ostertag, R. (2001). Neotropical secondary forest succession: changes in structural and functional characteristics. Forest Ecology and Management 148: 185-206. https://doi.org/10.1016/S0378-1127(00)00535-1

[2] Hounkpèvi, A., Yévidé, A. S. I., Ganglo, C. J., Devineau, J-L., Azontonde, H. A., Adjakidje, V., De Foucault, B., Agbossou, K. E. (2011). Structure and ecology of Diospyros mespiliformis Hochst forest. ex A. DC. and Dialium guineense Willd. in the reserve of Massi (Lama forest), Benin. Bois et forêts des tropiques: $308,33-45$.

[3] FAO. (2020). Global Forest Resources Assessment 2020: Main report. Rome. https://doi.org/10.4060/ca9825en.

[4] Mama, A., Bamba, I., Sinsin, B., Bogaert, J., De Cannière C. (2014). Deforestation, savanization and agricultural development of savanna-forest landscapes in the Sudano-Guinean zone of Benin. Bois et Forêts des Tropiques, No324 (4), 11p. http://bft.cirad.fr/cd/BFT_322_65-75.pdf

[5] Imorou, I. T., Arouna, O., Zakari, S., Djaouga, M., Thomas, O., Kinmadon. G. (2019). Assessment of deforestation and forest degradation in protected areas and village lands in the cotton basin of Benin. OSFACO Conference: Satellite images for the sustainable management of territories in Africa, Mar 2019, Cotonou, Bénin. HAL-02189556.

[6] Kakpo, T., Akpona, A. H., Kouchade, M., Awessou, B. (2012). Functional framework. Forest and River Land Management Project. General Direction of Forests and Natural Resources. Ministry of the Environment, Habitat and Town Planning,
Republic of Benin. $42 \mathrm{p}$.

[7] FAO. (2015). Forest Resources Assessment. Food and Agriculture Organization of the United Nations. FRA data directory. 198p.

[8] Ganglo, C. J., De Foucault, B. (2006). Plant communities, forest sites identification and classification in Toffo reserve, South Benin. Bois et Forêts des Tropiques, 288 (2): 25-38. https://doi.org/10.19182/bft2006.288.a20313

[9] Cerutti, P. O., Nasi, R., Tacconi, L. (2008). Sustainable forest management in Cameroon needs more thanapproved forest management plans. Ecology and Society 13 (2): 36. http://www.ecologyandsociety.org/vol13/iss2/art36/.

[10] Hitimana, J., Kiyiapa, J. L., Njunge, J. T. (2004). Forest structure characteristics in disturbed and undisturbed sites of Mt. Elgon Moist ower Montane Forest, werstern Kenya. Forest Ecology and Management, 194: 269-291. https://doi.org/10.1016/j.foreco.2004.02.025

[11] Ganglo, C. J. (2005). Plant communities of undergrowth, identification and characterization of forest stations: case of a wood in Benin. Bois et Forêts des Tropiques, $N^{\circ} 285$ (3).

[12] Noumon, J. C., Ganglo, J. C. (2005). Phytosociology applied to forest management: case of Koto forest area (Department of Zou, Benin Center). Acta Botanica Gallica, 152 (3): 421-426. https://doi.org/10.1080/12538078.2005.10515500

[13] Noumon, C. J., Ganglo, C. J., Azontondé, A. H., De Foucault, B., Adjakidjè, V. (2006). Phytocenosis of Mallotus oppositifolius (Geisl.) Müll. Arg and Deinbollia pinnata Schumach. \& Thonn. in the undergrowth of the teak plantations of Benin Center. Journal of Botanique de la Société Botanique de France. 36, 35-61.

[14] Aoudji, A. K. N., Ganglo, C. J. (2006). Phytosociology applied to forest management: case of the forest of Pahou (Department of Atlantique, South Benin). Journal of Botanique de la Société Botanique de France, 34 (3-5): 89-92. DOI: 10.1080/12538078.2005.10515500.

[15] Aoudji, A. K. N., Ganglo, C. J., Adjakidjè, V., De Foucault, B., Azontondé, A. H. (2006). Phytocenosis of Barteria nigritana Hook. f. and Rauvolfia vomitoria Afzel. in the undergrowth of fuelwood plantations of the classified forest of Pahou, South-Benin. Journal de Botanique de la Société Botanique de France. 34, 81-88.

[16] Tohngodo, B. C., Ganglo, J. C., Agbossou, K. E. (2006). Phytosociology as a tool for identifying and characterizing forest stations. Acta Botanica Gallica, 153 (1), 135-140. https://doi.org/10.1080/12538078.2006.10515528.

[17] Sokpon, N. (1995). Ecological research on the dense semi-deciduous forest of Pobè in southeastern Benin. Plant communities, structure, natural regeneration and litter fall. $\mathrm{PhD}$ thesis, Université libre de Bruxelles, interfaculty section of agronomy, botany, systematics and phytosociology laboratory, Belgique, 350p. ulbcat.ulb.ac.be:35671. https://difusion.ulb.ac.be/vufind/Record/ULB-DIPOT:oai:dipo t.ulb.ac.be:2013/212570/Details.

[18] Yehouenou-Tessi, D. R., Akouèhou, G. S., Ganglo, J. C. (2012). Structural, ecological and ethnobotanical characteristics of populations of Antiaris toxicaria (Pers) Lesch and Ceiba pentadra (L.) Gaertn in the relict forests of South Benin. International Journal of Biological and Chemical Sciences. 6 (6): 5056-5067. https://doi.org/10.4314/ijbcs.v6i6.24 
[19] Noumon, J. C., Ganglo, J. C. (2005). Phytosociology applied to forest management: case of the forest perimeter of Koto (Department of Zou, Center-Benin), Acta Botanica Gallica, 152: 3 , 421-426. https://doi.org/10.1080/12538078.2005.10515500.

[20] Gangnibo, C. N., Aoudji, A. K. N., Ganglo J. C. (2014). Study of plant groups in the classified forest of Agrimey: application to the identification and characterization of forest stations. International Journal of Biological and Chemical Sciences, 8 (4): 1445-1457. http://dx.doi.org/10.4314/ijbcs.v8i4.9

[21] Herrero-Jáuregui, C., Sist, P. L., Casado, M. A. (2012). Population structure of two low-density neotropical tree species under different management systems. Forest Ecology and Management. 280: 31-39. https://doi.org/10.1016/j.foreco.2012.06.006

[22] Comita, S. L., Condit, R., Hubbel, S. (2007). Developmental changes in habitat associations of tropical trees. Journal of Ecology, 95: 482-492. https://doi.org/10.1111/j.1365-2745.2007.01229.x

[23] Nishimura, S., Yoneda, T., Fujii, S., Mukhtar, E., Kanzaki, M. (2008). Spatial patterns and habitat associations of Fagaceae in a hill dipterocarp forest in Ulu Gadut, West Sumatra. Journal of Tropical Ecology. 24: 535-550. https://doi.org/1017/S0266467408005269

[24] Chessel, D., Dufour, A. B., Thioulouse, J. (2004). "The ade4 Package - I: One-table Methods." R News, 4 (1), 5-10. https://cran.r-project.org/doc/Rnews/.

[25] Shannon, C. E. (1948) A Mathematical Theory of Communication. Bell System Technical Journal, 27, 379-423, 623-656.
[26] Shannon, C. E., and Weaver, W. W. (1963). The mathematical theory of communications. University of Illinois Press, Urbana, $117 \mathrm{p}$.

[27] Feeley, J. K., Wright, S. J., Supardi, N. M. N., Kassim, A. R., Davies, J. S., (2007). Decelerating growth in tropical forest trees. Ecology Letters, 10: 1-9. https://doi.org/10.1111/j.1461-0248.2007.01033.x

[28] Ali, R., Odjoubere, J., Tente, A., Sinsin, A.B. (2014). Floristic characterization and analysis of the forms of pressure on the sacred or community forests of the Lower Ouémé Valley in southeastern Benin. Afrique Science 10 (2): 243- 257. $\mathrm{http}: / / \mathrm{www}$.afriquescience.info/document.php?id=3458. ISSN 1813-548X.

[29] Shorohova, E., Kuuluvainen, T., Kangur, A., Kalev Jogiste, K. (2009). Natural stand structures, disturbance regimes and successional dynamics in the Eurasian boreal forests: a review with special reference to Russian studies. Annals of Forest Science, 66 (2009) 201. 21p. DOI: 10.1051/forest/2008083.

[30] Ahouandjinou, B., Yédomonhan, H., Adomou, A. C., Tossou, M. G., Akouègninou, A. (2017). Floristic diversity and structural characterization of Ouoghi reserve forest in the Sudano-Guinean zone (Center-Benin). European Scientific Journal, vol. 13, $\mathrm{N}^{\circ} 12.24$ pages. http://dx.doi.org/10.19044/esj.2017.v13n12p400

[31] Tchibozo, E. A., Domingo, E. (2014). Occupation of soil and analysis of spatial structure in classified forest: Case of Ketou and Dogo, In East-Center of Benin. Leïdi laboratory geography review -ISSN 0851-2515, $\mathrm{N}^{\circ} 12$. 